Peer review: This article has been subject to a double blind peer review process

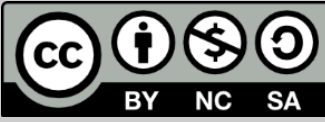

C Copyright: The Authors. This article is issued under the terms of the Creative Commons Attribution NonCommercial Share Alike License, which permits use and redistribution of the work provided that the original author and source are credited, the work is not used for commercial purposes and that any derivative works are made available under the same license terms.

\section{Reconstructing the Sensory Experience of Caracalla's Supplication at the Pergamene Asclepieion}

\author{
Ghislaine van der Ploeg* \\ Department of Classics and Ancient History, University of Warwick \\ *Correspondence: G.van-der-Ploeg@warwick.ac.uk
}

\begin{abstract}
An imperial visit to a city was a grand affair, from the emperor's adventus, to sacrificing at local shrines, to the commemorative acts which followed. This article aims to examine the multi-sensory impact of an imperial visit to a sanctuary and the lasting effects of these supplications via the case study of Caracalla's worship of Asclepius in Pergamum in AD 213-14. This visit was commemorated on a series of medallions struck shortly after the event, which depict the acts of the emperor as he moved through the city to the Asclepieion and from secular to sacred space.

This article will bring new depth to the study of imperial and divine relations as well as address the issue that often events such as these were not as neat and as clean-cut as is sometimes imagined nowadays. This article will address the following questions: How does our understanding of an imperial visit and supplication change when the sensory nature of such an event is examined? And for what reason are the senses manipulated in these images?
\end{abstract}

Keywords: Asclepius, Caracalla, Pergamum, Senses, Sacrifice, Medallions

\section{Introduction}

An imperial visit to a city was a grand affair. From the emperor's adventus, the ritual surrounding his arrival into a city, to sacrificing at local shrines, to the commemorative acts which followed. This article aims to reconstruct the multi-sensory impact of an imperial visit to a sanctuary via the case-study of Caracalla's worship of the god Asclepius at Pergamum in Asia Minor in AD 213-14. This visit was commemorated on a series of medallions struck shortly after the event, which depict the acts of the emperor as he moved through the city to the Asclepieion and from secular to sacred space. These medallions offer a two-dimensional image of an imperial supplication and it is possible for the multi-sensory 
nature impact of such an event to become lost in scholarly discourse. This article aims to bring new depth to the study of imperial and divine relations as well as to address the issue that often events such as these were not as neat and clean-cut as they are depicted in imagery. It will focus specifically on the sensory nature of sacrifice and the iconography of its depiction. The following questions will be addressed: How does our understanding of an imperial visit and supplication change when the sensory nature of such an event is examined? And for what reason are the senses manipulated in these images? The reasons behind Caracalla's supplication will first be examined and this article will then move on to look at the series of medallions and their depiction of the events which took place during the adventus. There is some debate as to whether these issues should be referred to as coins or medallions. Medallions differ from coins as they were generally presentation pieces which were larger and heavier than regular coins in circulation (Rowan, 2014:109). The largest number of medallions were struck during Hadrian's reign. Medallions were struck in order to commemorate the most important events which had occurred during the preceding year, and were a way of showing the owner's close relationship with the emperor (Rowan, 2014: 111). Rowan, analysing medallions struck under Antoninus Pius, states that the audience for these medallions would have been the elite inner circle, who would have had knowledge of the events which were depicted (Rowan, 2014: 115). Medallions are often found within tombs and are not generally found in archaeological contexts together with regular coin issues (Rowan, 2014: 110). As such, the term medallion seems more befitting the Caracallan issue and will, therefore, be referred to as a series of medallions.

\section{Caracalla and Pergamum}

Around AD 213-214 Caracalla visited the Pergamene Asclepieion in order to supplicate the god there as part of a grander tour of Asia Minor. Two sources give an explanation for why the emperor travelled such a great distance to seek healing:

For he was sick not only in body, partly from visible partly from secret ailments, but in mind as well, suffering from certain distressing visions, and often he thought he was being pursued by his father and by his brother, armed with swords. [...] He received no help from Apollo Grannus, nor yet from Aesculapius or Serapis, in spite of his many supplications and his unwearying persistence. For even while abroad he sent to them prayers, sacrifices and votive offerings, and many couriers ran hither and thither every day carrying something 
of this kind; and he also went to them himself, hoping to prevail by appearing in person, and did all that devotees are wont to do; but he obtained nothing that contributed to health (Dio Cassius, 1927: 78.15.3-7).

And:

After this Antoninus made what administrative arrangements were possible in the cities and then left for Pergamum in Asia, where he was anxious to have treatment at the shrine of Aesculapius [sic]. When he arrived there, he made as much use of the incubation treatment as he wanted and then went to llium. (Herodian, 1969: 4.8.3).

Dio's passage describes Caracalla's dreams, in which the emperor hallucinates that he is being pursued by his father and brother who are intent upon murdering him in revenge for his part in Geta's death (SHA Caracalla, 1924: 2.4). Both passages describe how Caracalla's travels around his Empire and also his supplications of various gods, not just Asclepius, were connected with his desire to find a cure (Fowden, 2005: 545). Rowan cautions that the motivations provided in these sources should not be taken at face value as it is possible that Caracalla either could have set out with the explicit intention of worshipping these gods, or he could just have worshipped the locally important deities of the cities he visited on his travels (Rowan, 2013, 113: 115). It was important for each emperor to legitimize their reigns but probably even more imperative for Caracalla to do so as he needed to acquire an identity other than one of fratricide in the aftermath of Geta's death. Dio's account of Caracalla's life was very biased against the emperor and Caracalla was consistently depicted in the worst light, and stated to be cowardly, deceitful and stupid (Dio Cassius, 1927: 77.14). Dio probably wrote his account eight years after Caracalla's accession and two years after his death. Whittacker (1969: xiv) argues that Herodian's work was likely composed sometime after AD 244. The author contrasts Geta and Caracalla, although both are portrayed in a negative light from the start. Herodian states that Severus trained both in self-control (Herodian, 1969: 3.10.2) but both were corrupted by luxury and their mutual antagonism (Herodian, 1969: 3.10.3-4). His portrayal of the brothers changes during his description of the British campaign, when Herodian begins to portray Geta in a better light, showing Caracalla to be the worse of the two. This indicates that both sources have an inherent bias towards Caracalla. 


\section{Miniature Monuments}

These medallions were struck by the city of Pergamum shortly after Caracalla's visit and document his movements in Pergamum. They were issued by the local mint and were 'miniature monuments', documenting the emperor's patronage of Asclepius and Pergamum (Rowan, 2013: 136). Calling them monuments is an important part of this exploration into the sensory nature of the adventus as they are generally idealised representations. Hamilakis in his work on the 'Archaeology of the Senses' provides a useful parallel. He argues that early photographs, taken shortly after this technology was invented and became available for public use, most commonly show ancient monuments. However, these were completely stripped bare of any evidence of contemporary Greek life and were also stripped of the senses. By removing any contemporary connections and displaying local places in a sanitised way these photographers placed greater emphasis on the past than the present, offering a sense of monumentality and eternity in their images (Hamilakis, 2014: 44).In effect, these photographers had the same goal as the issuers of the Pergamene medallions, which presented a timeless, monumental, and sanitised representation of the adventus, evoking its monumentality but also removing the senses as they did not fit their monumental purposes. The images of the adventus show a cleaned up version of events, yet the senses are vital for human social experience and would have formed a large part of the experience of the adventus. Class, gender, age, race, and ethnicity all play a part in the experience of the senses, meaning that every individual will have an unique experience (Hamilakis, 2014: 1- 2).

The first issuing magistrate of these medallions was Marcus Caerelius Attalus, as indicated by their inscription. Yet, two other magistrates' names also occur, namely Julius Anthimus and Marcus Aurelius Alexandrus, indicating that they were re-struck later on. There are slight differences between these issues as, for example, Caracalla appears both in military and civilian garb on Attalus' medallions but only in military dress on Anthimus' medallions (Burrell, 2004: 31). As the medallions were struck as part of a series and individually, it is more likely that the events they show actually took place in some form (Johnston, 1983: 60). Asclepius and Caracalla are depicted as equals and they show both Asclepius as a symbol of the healing the emperor received in Pergamum, but also the emperor's personal devotion to the god (Weisser, 2005: 137; Kadar, 1986: 34-5). They follow Caracalla's movements through civic space. This space was perceived and shaped via cultural expectations, human needs, and individual experiences (Scott, 2012: 1 \& 4). Each individual would have had a different experience of the event, depending on their sensory input, as each of the senses had a varied range and 
sphere of influence. Sacred space is especially well suited for a study on the senses as it plays a vital role in the articulation and transmission of socio-cultural practices. It is, furthermore, the physical embodiment of the memory of a community and, as such, it reflects and expresses social behaviours, meanings, and beliefs. Spiritual cohesion was maintained and reinforced via religious space and architecture. These spaces could be connected to each other across a city scape via religious rites such as processions. These processions were an especially multi-sensory experience and Caracalla's adventus would have been experienced differently by each and every viewer (for more on processions see Ostenberg, 2009, and Ostenberg, Malmberg and Bjørnebye, 2015). The senses are heightened by the unfamiliar, such as the once in a life time event of an imperial visit, making the event even more overwhelming. The more public, the more alert the senses are and they operate in different directions.

\section{Asclepius, Caracalla, and the Multi-sensory Act of Sacrifice}

In this section the iconography of each medallion will briefly be described. Then focussing on a select few, this article will examine how a multi-sensory approach to viewing these medallions can enrich understanding of the events which took place. The article will then discuss the sensory impact, or rather lack thereof, of the sacrificial scenes which were depicted on the medallions.

Sacrifice is now understood to be the central ritual act in Graeco-Roman religion (Faraone and Naiden, 2012: 1; Scheid, 2007) and there were usually four phases to the sacrificial process: immolation; transferring the animal from the human sphere to the divine; the slaughter of the animal; and the sacred meal which concluded this process. Prayers would have always been said throughout the rite in order to gain the god's attention (Pliny, 1963: 28.10; Gilhus, 2006: 115). In Roman religion the most commonly sacrificed animals were pigs, sheep, and cattle, although the importance of bloodless sacrifices should not be underestimated. Cattle were the mostly commonly dedicated animals during a public sacrifice, due to the cost involved and also because they provided more meat than the other kinds of animals (Rüpke, 2007: 152). Scholars such as Detienne and Vernant (1979) and Burkert (1972) have argued that in the Greek world sacrifice played an important role in establishing social hierarchies but Scheid has recently described how this hierarchy of social sharing was negated by the advent of Empire, especially in the 2nd and 3rd centuries AD (Scheid, 2012: 88). However, status did still matter as those who carried out all of the physically exerting work during the sacrifice such as leading the victim to the altar and performing the act of killing- 
were generally low-born, freedmen, or slaves (Gilhus, 2006, 116). Their lesser status is shown by depicting them as being smaller than the officiant, dressed in different clothing, or sometimes even being naked which indicates that the visual senses are being manipulated here (Van Straten, 1995: 168). This visual distinction happens further, as in Greek art the officiant was often bearded and the assistant beardless. On Roman reliefs the major officiants are shown wearing togas and the sacrificant generally had a covered head. The assistant was often shown bare-chested, which would have been done so out of practical considerations for the blood spilled during the ritual (Weddle, 2013: 151; Gilhus, 2006: 116). However, coins did not always follow the same iconographic motifs as are found in Graeco-Roman art. These hierarchies are also visible in the human-god divide. The god always ate first, which was a clear sign of his predominant status and he received the best portions of the animal such as the exta, the entrails, and the heart from the 3rd century BC onwards. (Rüpke, 2007: 145; Pliny, 1940: 11.186).

The reverse of the first Asclepieian medallion of the series shows an equestrian Caracalla wearing military dress standing in front of a turreted female figure, the Tyche of Pergamum, who holds a statue of Asclepius (BMC Mysia: 154.319;

http://www.acsearch.info/search.html?id=111068). The emperor has just entered the city and is being greeted by its deities. By connecting Asclepius and Tyche, the chief protective deity of a city, from the outset it was clear that Asclepius was a polis-deity, as was his presence at Caracalla's adventus. Harl describes an adventus as a dramatic event where the emperor, coming into the city was greeted by the city's magistrates, population, and, most importantly, its gods, who were carried in the form of statues from their sanctuaries to greet the emperor. This was aimed at fostering a positive feeling in the population towards the emperor and legitimising his rule (Harl, 1987: 52). The emperor then worshipped at a sanctuary and gave benefactions. Festivals and games were also often held. There was more to an adventus than just the emperor's arrival into the city and immense preparations preceded the actual arrival. The city was beautified with garlands, torches, flowers, laurel-leaves, colourful clothes, incense, and was also cleaned top to bottom (Lehnen, 1997: 83 \& 120; Dio Cassius, 1927: 63.4.3, 74.1.4; Josephus, 1928: 7.71). The cityscape was drastically altered for the adventus and became a multi-sensory extravaganza as sounds and smells do not respect boundaries and, therefore, freely move between public and private space (Betts, 2011: 123). An ancient spectacle was, thus, a multi-sensory experience where sight, smell, touch worked together (Bradley, 2013: 138). On the medallion, the emperor holds his hand up in greeting which was a typical image of an advent 
from the time of Trajan onwards (Harl, 1987: 53-4). It was also common for an emperor to greet Tyche at this point. Only the emperor and the gods are depicted here and in a very static pose. The noisy crowds which must have come to see the emperor arrive in the city are missing. The issue of light also plays a part here. Buildings would have flanked the streets the emperor moved through, casting shadow upon his path. It is impossible to tell at which point the emperor met the gods, possibly at the city gates but possibly at their temples where the light would have been better.

The second medallion (BMC Mysia: 154.320;

http://www.acsearch.info/search.html?id=1372306) shows Caracalla standing in front of Tyche again, who holds a statue of Asclepius. A soldier bearing a statue of Nike stands behind the equestrian Caracalla. The third medallion depicts Caracalla, still on horseback, standing in front of a statue of Asclepius on a tall pedestal (BMC Mysia: 155.321;

http://coinproject.com/coin detail.php?coin=285048). A soldier follows the emperor. These images give a clear but sanitised idea of the actions undertaken by Caracalla in Pergamum. In reality, the emperor's procession through the city would have been a grand affair with noisy crowds cheering and jostling each other for a better view. Small portable incense holders would transform the olfactory cityscape, as would smells provided by street vendors hawking their wares and selling snacks for the viewers. Visually the emperor would have had an effect, dressed to impress on horseback. The senses would have been omnipresent but they have not been represented here. The focus is solely on the emperor and the gods.

On the forth medallion (BMC Mysia: 155.322) the emperor enters sacred space. The medallion shows Caracalla holding a spear in his left hand and a patera, a drinking vessel, in his right hand, above a lit altar while Asclepius stands on the other side of the altar holding his snake-staff. This is the first medallion which illustrates the sacrifices undertaken by Caracalla as he is depicted undertaking rites which took place prior to the sacrifice and often entailed the offering of bloodless sacrifices. All one needed to make a sacrifice was an altar and an offering.

The fifth medallion in the series (BMC Mysia: 155.323; http://www.wildwinds.com/coins/ric/caracalla/ pergamon vFritze 73.jp g) shows Caracalla holding a patera in his right hand and a globe in his left. He faces Asclepius who is holding his snake-staff. Between them stands a bull. The visual element was very important during sacrifice as the animal should be pure and unblemished, in perfect physical condition. If it was anything less than this, the god could reject the prayer and offering (Petropoulou, 2010: 41). Noise, motion, sensitivity, and 
appetite were all signs of a good victim (Naiden, 2012: 65). The animal should be lively but not in an indecorous way, meaning that it should act in a way compatible with the conduct of sacrifice. As Weddle states: 'The proper control of the sensory elements of sacrifice was vital to correct ritual practise.' (Weddle, 2013: 138). Supplicants would only make a sacrifice if they knew a god was in residence at a sanctuary at that time, or else the act could go unnoticed. Prayers and sacrifice attracted the god's attention but music and dance were other ways to make oneself be heard (Naiden, 2013: 60). Music was omnipresent during the rite of sacrifice as it would drown out any noises that the animal made and other incidental noises, including those made by humans, which could negate the sacrifice (Naiden, 2012: 61; Weddle: 2013, 138). The sacrifice was an overwhelming affair yet no sign of this can be found on the medallions where most actions are static and musicians are not represented at all.

The sixth medallion (BMC Mysia 155.324; http://www.acsearch.info/search.html?id=673375) shows Caracalla holding a patera and a scroll, standing in front of a temple in which a cult-statue of Asclepius can be seen. An attendant stands on the left, striking at the bull who is tied to a ring by his nose. It is possible that Caracalla actually sacrificed a hecatomb, a large public sacrifice which originally consisted of one-hundred oxen, to Asclepius (Nollé, 2003: 413). The seventh medallion depicts a togate Caracalla holding a patera, standing to the left of a temple. Asclepius stands within the temple. Between the two, the attendant holds a raised axe and is preparing to strike the bull (BMC Mysia: 156.325;

http://www.wildwinds.com/coins/ric/caracalla/ pergamum SNGFr 223 0.jpg). In Classical and Archaic Greek art there are no images of cattle being sacrificed other than those where the axe is being raised over the animal's head. The actions which occurred after this, such as the slitting of the animal's throat, are never depicted (Van Straten, 1995: 107). These animals with their garlands and gilded horns made a grand visual spectacle. Roman sacrificial ritual dictated that an animal should be led willingly to the altar and would not make a massive spectacle of protest as this could negate the sacrifice. Ideally it should appear willing to die (Juvenal, 2004: 12.1-6; Aldrete, 2012: 29). However, representations depict them as being restrained by ropes, with sometimes as many as three legs tied up, and being dragged or led to the altar. In Roman religion a certain amount of resistance was also expected but even so, the more docile an animal the better. The idea of the concealment of violence has long been a part of scholarly discourse on sacrifice. However, close study of iconographical images such as this has led scholars to reject this idea and acknowledge the practical difficulties of 
sacrificing such a large and powerful animal like a bull. A large bovine who has its throat slashed will still take some time to bleed to death. It will take about 20-30 seconds for it to lose consciousness. This is more than enough time for the animal to display a negative reaction to being killed with plenty of noises and movement. This in turn would destroy the fiction of willing victimhood (Aldrete, 2012: 30). At the altar it seems that a Roman victim was not restrained in any meaningful way and its head was usually just held loosely by attendants. This was a problem as a very large and unbound animal had to be reduced to an inactive and insensible state without it being allowed to display any kind of negative reaction. As part of the ritual, the bull had to be kept in this insensate state for quite a long period of time while it bled to death. A sacrifice could also be considered invalid if only a small amount or no blood flowed from the bull, which meant that the animal needed to be given time to bleed freely (Virgil, 1999, 3.492; Aldrete, 2012, 31).

Weddle has undertaken an auto-ethnographic study of sacrifice by taking part in the mass animal sacrifice during the Kurban Bayram festival, held in Istanbul (Weddle, 2013: 142ff). Due to this experience, she was able to make some remarks on the behaviour of the bulls which were waiting to be sacrificed. She was especially taken aback by the docility of these animals which were being lead to their death. However, she also notes that when these animals do panic, they have the capacity to cause a mass stampede, which would be very dangerous to all involved (Weddle, 2013: $143,151)$. In antiquity, before the bull's throat was slit, it was first stunned with a blow to the head from a hammer or axe which would render it unconscious but still alive. However, it is not easy to stun an animal in this fashion as the blow had to be powerful enough to render the animal unconscious but not too much that it would kill it. The slightest movement on the bovine's part could negate the sacrifice (Aldrete, 2012: 30-1). Many representations of sacrifice have at least one victimarius, the sacrificial servant, kneeling by the head of the standing animal and pulling its head downwards. A cultrarius, the knife-wielder, often kneels beside the animal holding a knife at the ready. This was not a position optimal for an efficient killing as the best position for the stunning would be if the head was held parallel to the ground. Aldrete offers a new interpretation of events and argues that when an axe was used, and it was aimed at the neck instead, this would have severed the spinal column and killed the bull instantaneously. This would explain the odd angle shown in art as it would lay the vertebrae open and vulnerable, but even if the spinal cord was cut the autonomous functions of the animal's body would allow blood to circulate for some time after death and allow for the altar to be bled upon (Aldrete, 2012: 40-1). Sources show that the animal's throat was slit immediately after the 
popa, the one who stunned the animal, struck his blow. Examination of the medallion here indicates an absence of all these concerns. During the actual sacrifice, everything would have been done to ensure a minimum of movement and noise on the animal's part. After the bull's throat was slit, the smell and sight of gushing blood would have made a great sensory impact on the viewers, as it flooded over the altar. After the slaughter the sacrificial meat and wine were presented to the god in a fire, which was presented on the altar with sweet wine, mixing with the already overpowering smell of blood. Perfume would also be used to anoint the offering furthering the olfactory sensory nature of the offering (Scheid, 2012: 86).

The eighth medallion (BMC Mysia 156.326;

http://coinproject.com/coin detail.php?coin=282423) shows Caracalla saluting the Asclepieian snake which curls around a tree. Telesphorus, a god commonly associated with Asclepius, stands between the tree and the emperor. The ninth medallion (BMC Mysia: 156.327; see http://www.acsearch.info/search.html?id=813728) in the series depicts three temples. Asclepius is shown seated, holding a snake, in the centre temple. Other deities were placed in the two adjacent temples. Minute letters on the temple pediments identify the temples as those of Augustus on the left, Trajan on the right, and Caracalla in the middle (Burrell, 2004: 31). Smyrna also minted coins at this time depicting Caracalla's worship of the three main temples there (BMC Ionia: 288.402). These three temples housed a cult of the emperor as well as that of a deity. To be neokoros meant that a temple of the imperial cult was present in the city (Burrell, 2004: 1). This inscription indicates that Pergamum now had three such temples. Coins of Geta, in the guise of Augustus, dated to AD 209 mention that Pergamum was only twice neokoros and it is only after Caracalla's visit that this new inscription appears on coins and the grant should be dated to this time (Burrell, 2004: 30).

\section{Conclusion}

The medallions have a rich iconography dedicated to showing the viewer Caracalla's movements through Pergamum and demonstrate the high regard in which he held Asclepius. They show that he followed both religious and therapeutic rituals in search of healing and give a detailed synopsis of the emperor's actions within the city. Yet, on these representations the senses were removed entirely. Sacrifice was the easiest and most public way to show one's piety (Petropoulou, 2010: 86). Gordon argues, examining Trajan's representation on the Arch at Beneventum, that the focus has shifted here from the sacrificial scene to 
the emperor's presence. The whole event cannot be depicted because of lack of space and decisions about what to depict had to be made. The sacrificial scene here has been narrowed down to focus on the political fact of the sacrificial role of the emperor (Gordon, 1990: 203). This too can be seen occurring on the Pergamene medallions as their main focus was the emperor and his actions through the city.

The adventus was a political as well as a religious act. The main meaning of such a sacrificial scene was to preserve the imperial house, maintain the continuity of key institutions, and to bring these into relation with local social hierarchy through iconography (Gordon, 1990: 214). Only those who were pure were allowed to sacrifice, or else once again run the risk of the god rejecting the offering, and Caracalla's public sacrifice could be seen as a public exoneration of his part in Geta's murder and also aiding him to legitimise his rule (Gilhus, 2006: 117). In order to achieve these aims the senses had to be removed from the imagery showcased here. The noisy crowds served no purpose as the focus was on the emperor. Paraphernalia such as torches and incense holders, which would affect the sensory experience of the event, would also have detracted from the image of the emperor. The bull, the main offering and tool of human-divine communication is depicted smaller than the emperor. He too is static and shows little sign of struggle, noise, or movement. These sanitised images lend a hand in identifying the way in which the bull would be killed, minimising sound and movement on its part, but does not show the moment of killing with spurts of arterial blood or the blood-drenched altar. The senses were how each viewer experienced these events but they are deliberately removed here as they do not serve the purpose of these images. The issuers wished to show a version of events which eternalised and monumentalised the adventus and the emperor, just as the early photographers wished to do with their images of ancient sites. Only by sanitising these images and removing the senses could monumentality be achieved. 


\section{References}

Aldrete, G.S. (2012), 'Hammers, Axes, Bulls, and Blood; Some Practical Aspects of Roman Animal Sacrifice', JRS, 104, 28-50

Betts, E. (2011), Towards a multi-sensory experience of movement in the City of Rome', in Laurence, R. and D.J. Newsome (eds.) Rome, Ostia and Pompeii: Movement and Space, Oxford: Oxford University Press, pp.118132

Bradley, M. (2013), 'Colour as a Synaesthetic Experience in Antiquity', in S. Butler and A. Purves (eds.) Synasthesia and the Ancient Senses, Durham: Acumen Publishing, pp. 127-140

Braund, S. M. (2004), Juvenal, Cambridge (Mass.): Harvard University Press

Burkert, W. (1972), Homo Necans: Interpretationen altgriechischer Opferriten und Mythen, Berlin: W. de Gruyter

Burrell, B. (2004), Neokoroi: Greek Cities and Roman Emperors, Brill: Leiden

Cary, E. (1927), Dio Cassius Roman History, Volume XI, Books 71-80, Cambridge (Mass.): Harvard University Press

Detienne, M. and J.P. Vernant (1979), La cuisine de sacrifice en pays grec, Paris: Gallimard

Faraone, C.A. and F.S. Naiden (2012), 'Introduction' in C.A. Farone and F.S. Naiden (eds.) Greek and Roman Animal Sacrifice, Ancient Victims, Modern Observers, Cambridge: Cambridge University Press, pp. 1-12

Fowden, G. (2005), 'Late polytheism', in A. K. Bowman, P. Garnsey and A. Cameron (eds), The Cambridge Ancient History 12: The Crisis of Empire, A.D. 193-337, Cambridge: Cambridge University Press, 2nd edition), pp. $519-72$

Gilhus, I.S. (2006), Animals, Gods, and Humans: Changing Ideas to Animals in Greek, Roman and Early Christian Ideas, London: Routledge

Gordon, R. (1990), 'The Veil of Power: Emperors, Sacrificers, and Benefactors', in M. Beard and J. North (eds)., Pagan Priests: Religion and Power in the Ancient World, Baltimore: Johns Hopkins University Press, pp. 201-31

Hamilakis, Y. (2014), Archaeology and the Senses: Human Experience, Memory, and Affect, Cambridge: Cambridge University Press 
Harl, K. (1987), Civic Coins and Civic Politics in the Roman East AD 180275, University of California Press: Berkeley

Jones, W.H.S. (1963), Pliny Natural History, Volume VIII, Books 28-32, Cambridge (Mass.): Harvard University Press

Johnston, A. (1983), 'Caracalla's Path: The Numismatic Evidence', Historia: Zeitschrift für Alte Geschichte, 32 (1), 58-76

Kadar, Z. (1986), 'L'importance religieuse et artistique du culte d'Asklepios-Aesculapius sur les medailles de Caracalla a Pergmon', in Acta Classica Univ. Scient. Debrecen., 31-35

Lehnen, J. (1997), Adventus Principis. Untersuchungen zu Sinngehalt und Zeremoniell der Kaiserankunft in den Städten des Imperium Romanum, Frankfurt am Mein: Prismata

Magie, D. (1924), Historia Augusta, Volume II: Caracalla, Geta, Opellius Macrinus. Diadumenianus. Elagabalus. Severus Alexander. The Two Maximini. The Three Gordians. Maximus and Balbinus, Cambridge (Mass.): Harvard University Press

Naiden, F.S. (2012), Smoke Signals for the Gods, Oxford: Oxford University Press

Nollé, J. (2003), 'Caracallas Kur in Pergamon: Krankheit und Heilung eines römischen Kaisers im Spiegel der Münzen', Antike Welt 34, 409-417

Ostenberg, I. (2009), Staging the World. Spoils, Captives, and Representations in the Roman Triumphal Procession, Oxford: Oxford University Press

Ostenberg, I., S. Malmberg and J. Bjørnebye (eds.) (2015), The Moving City. Processions, Passages and Promenades in Ancient Rome, London: Bloomsbury

Petropoulou, M.-Z. (2010), Animal Sacrifice in Ancient Greek Religion, Judaism, and Christianity, 100 BC to AD 200, Oxford: Oxford University Press

Rackham, H. (1940), Pliny the Elder: Natural History, Volume III, Books 811, Harvard University Press: Cambridge (Mass.)

Rowan, C. (2013), Under Divine Auspices: Divine Ideology and the Visualisation of Imperial Power in the Severan Period, Cambridge: Cambridge University Press

Rowan, C. (2014), 'Showing Rome in the Round: Reinterpreting the 'Commemorative Medallions' of Antoninus Pius', Antichthon 48, 109-125

Rüpke, J. (2007), The Religion of the Romans, Polity: Cambridge 
Rushton Fairclough, H. and G.P. Goold (1999), Virgil Georgics, Cambridge (Mass.): Harvard University Press

Scheid J. (2007), 'Sacrifices for Gods and Ancestors', in J. Rüpke J. (ed.), A Companion to Roman Religion, Oxford: Blackwell, pp. 263-272

Scheid J. (2012), 'Roman Animal Sacrifice and the System of Being', in C.A. Faraone and F.S. Naiden, (eds.), Greek and Roman Animal Sacrifice, Ancient Victims, Modern Observers, Cambridge: Cambridge University Press, pp. 84-92

Scott, M. (2012), Space and Society in the Greek and Roman Worlds. Key Themes in Ancient History, Cambridge: Cambridge University Press

Thackeray, H. St. J. (1928), Josephus The Jewish War, Volume III, Books 57, Cambridge (Mass.): Harvard University Press

Van Straten, F. (1995), Hiera Kala: Images of Animal Sacrifice in Archaic and Classical Greece, Brill: Leiden

Weddle, C. (2013), 'The Sensory Experience of Blood Sacrifice in the Roman Imperial Cult' in J. Day (ed.) Making Sense of the Past: Toward a Sensory Archaeology, Southern Illinois University Press: Carbondale, pp. 137-159

Weisser, B. (2005), 'Pergamon as Paradigm', in C. Howgego, V. Heuchert and A. Burnett (eds.), Coinage and Identity in the Roman Provinces, Oxford University Press: Oxford, pp. 135-142

Whittacker, C.R. (1969), Herodian: History of the Empire, Volume I, Books 1-4, Cambridge (Mass.): Harvard University Press

\section{To cite this article:}

Van der Ploeg, G. (2016). Reconstructing the Sensory Experience of Caracalla's Supplication at the Pergamene Asclepieion. Exchanges: The Warwick Research Journal, 3(2), 185-198. Retrieved from: http://exchanges.warwick.ac.uk/index.php/exchanges/article/view/78 